\title{
Stromal cell-derived factor-1 G801A polymorphism and the risk factors for cervical cancer
}

\author{
ANDRZEJ ROSZAK ${ }^{1,2}$, MATTHEW MISZTAL $^{3}$, ANNA SOWIŃSKA ${ }^{4}$ and PAWEŁ P. JAGODZIŃSKI ${ }^{3}$ \\ ${ }^{1}$ Department of Radiotherapy and Gynecological Oncology, Greater Poland Cancer Center, Poznań 61-866; \\ Departments of ${ }^{2}$ Electroradiology, ${ }^{3}$ Biochemistry and Molecular Biology, and ${ }^{4}$ Computer Science and Statistics, \\ Poznań University of Medical Sciences, Poznań 60-781, Poland
}

Received March 21, 2014; Accepted January 2, 2015

DOI: $10.3892 / \mathrm{mmr} .2015 .3315$

\begin{abstract}
Although certain studies have demonstrated no association between the stromal cell-derived factor-1 (SDF1-3') G801A single nucleotide polymorphism (SNP) and cervical carcinoma, the interactions between the SDF1-3' G801A SNP and contraceptive use, menopausal status, parity and tobacco smoking remain to be fully elucidated. Using polymerase chain reaction-restriction fragment length polymorphism, the distribution of SDF1-3' G801A genotypes in patients with cervical cancer $(n=462)$ against control groups $(n=497)$ was investigated. Logistic regression analysis, adjusting for age, pregnancy, oral contraceptive use, tobacco smoking and menopausal status, did not identify the SDF1-3' G801A polymorphism as a genetic risk factor for cervical cancer. The adjusted odds ratio (OR) for patients with the $A / G$, vs. $G / G$ genotype was 1.203 , with a $95 \%$ confidence interval (CI) of 0.909-1.591 ( $\mathrm{P}=0.196)$. The adjusted OR for the A/A, vs. $\mathrm{G} / \mathrm{G}$ genotype was $1.296(95 \% \mathrm{CI}=0.930-1.807 ; \mathrm{P}=0.125)$ and for the $\mathrm{A} / \mathrm{A}$ or $\mathrm{A} / \mathrm{G}$, vs. G/G genotype was $1.262(95 \%$ $\mathrm{CI}=0.964-1.653 ; \mathrm{P}=0.090)]$. The $\mathrm{P}$-value of the $\chi^{2}$ test of the trend observed for the SDF1-3' G801A polymorphism was at the borderline of being statistically significant $\left(\mathrm{p}_{\text {trend }}=0.0484\right)$. Stratified analyses between the distribution of the SDF 1-3 G801A genotypes and cervical cancer risks demonstrated that this polymorphism may be a risk factor for patients with a positive history of tobacco smoking $(1.778 ; 95 \% \mathrm{CI}=1.078-2.934$; $\mathrm{P}=0.0235$ ). These findings suggested that the SDF1-3' G801A polymorphism may be a genetic risk factor for cervical cancer in patients with a positive history of tobacco smoking.
\end{abstract}

Correspondence to: Dr Paweł P. Jagodzinski, Department of Biochemistry and Molecular Biology, Poznań University of Medical Sciences, 6 Święcickiego, Poznań 60-781, Poland

E-mail: pjagodzi@am.poznan.pl

Key words: cervical carcinoma, stromal cell-derived factor-1, polymorphisms

\section{Introduction}

Cervical tumors are the most common type of gynecological malignancy worldwide and constitute the tenth most frequent type of cancer occurring in females in developed countries $(1,2)$. The number of young females affected by cervical cancer has been increasing (1-3). Cervical carcinogenesis encompasses the transformation of normal cervical epithelium to cervical intraepithelial neoplasia (CIN), which may develop into an invasive cervical tumor $(4,5)$. There are several risk factors for cervical cancer, including human papillomavirus, impairment of the immune system, expression of tumor suppressor genes and gain of function mutations in proto-oncogenes $(4,5)$. In addition, contraceptive use, tobacco consumption, age and environmental exposures are also considered possible causative factors in cervical cancerogenesis (6). C-X-C motif chemokine 12 is a chemokine, also termed stromal cell-derived factor-1 (SDF1), which binds to the CXCR4/CXCR7 receptors (7).

The human $S D F 1$ gene is expressed as $\alpha$ and $\beta$ alternative splice variants (8). SDF1 is involved in lymphopoiesis and myelopoiesis and attracts lymphocytes, megakaryocytes, endothelial cells and stem cells (9-11). In addition, the interaction of SDF1 with CXCR4 controls the embryonic growth of vascular, cardiac, neuronal and craniofacial systems (12). However, the binding of SDF1 to CXCR4 contributes to the progression of cancer of the colon, pancreas, ovaries, prostate, lung, stomach, mouth, breast and skin, in addition to cervical cancer (13-21).

$S D F 1$ is present in common genetic variants due to a $\mathrm{G} 801 \mathrm{~A}$ transition in the 3'-untranslated region (rs 1801157) (22). The possible role of the SDF1-3' A variant in the increased levels of transcription and protein has been reported (22). Certain studies have demonstrated no association between the $S D F 1-3$ ' G801A single nucleotide polymorphism (SNP) and cervical carcinoma $(23,24)$, however, the interaction between the SDF1-3' G801A SNP with other known risk factors of cervical cancer remain to be fully elucidated. In the present study, the SDF1-3' G801A genotype and allele frequencies were investigated in patients with cervical cancer $(\mathrm{n}=462)$ and healthy controls $(n=497)$ in the Polish population, stratified based on contraceptive use, menopausal status, parity and history of tobacco smoking. 
Table I. Clinical and demographic characteristics of patients and controls.

\begin{tabular}{|c|c|c|}
\hline Characteristic & $\begin{array}{c}\text { Patient }(\mathrm{n}=462) \\
\mathrm{n}(\%)\end{array}$ & $\begin{array}{c}\text { Control }(\mathrm{n}=497) \\
\mathrm{n}(\%)\end{array}$ \\
\hline Mean age (years) $\pm \mathrm{SD}^{\mathrm{a}}$ & $52.4 \pm 9.4$ & $51.9 \pm 11.2$ \\
\hline \multicolumn{3}{|l|}{ Tumor stage } \\
\hline IA & $63(13.6)$ & \\
\hline IB & $62(13.4)$ & \\
\hline IIA & $56(12.1)$ & \\
\hline IIB & $57(12.3)$ & \\
\hline IIIA & $146(31.6)$ & \\
\hline IIIB & 55 (11.9) & \\
\hline IVA & $11(2.4)$ & \\
\hline IVB & $12(2.6)$ & \\
\hline \multicolumn{3}{|l|}{ Histological grade } \\
\hline G1 & $89(19.3)$ & \\
\hline $\mathrm{G} 2$ & $147(31.8)$ & \\
\hline G3 & $101(21.9)$ & \\
\hline Gx & $125(27.0)$ & \\
\hline \multicolumn{3}{|l|}{ Histological type } \\
\hline Squamous cell carcinoma & $383(82.9)$ & \\
\hline Adenocarcinoma & $62(13.4)$ & \\
\hline Other & $17(3.7)$ & \\
\hline \multicolumn{3}{|l|}{ Pregnancy } \\
\hline Never & $55(11.9)$ & 59 (11.9) \\
\hline Ever & $407(88.1)$ & $438(88.1)$ \\
\hline \multicolumn{3}{|l|}{ Oral contraceptive pill use } \\
\hline Never & $250(54.1)$ & $281(56.5)$ \\
\hline Ever & $212(45.9)$ & $216(43.5)$ \\
\hline \multicolumn{3}{|l|}{ Tobacco smoking } \\
\hline Never & $298(64.5)$ & $328(66.0)$ \\
\hline Ever & $164(35.5)$ & $169(34.0)$ \\
\hline \multicolumn{3}{|l|}{ Menopausal status } \\
\hline Premenopausal & $165(35.7)$ & $195(39.2)$ \\
\hline Postmenopausal & $297(64.3)$ & $302(60.8)$ \\
\hline \multicolumn{3}{|l|}{ HPV genotype } \\
\hline 16 and 18 & $315(68.2)$ & \\
\hline $16,18,31,33,35,39,45,51,52,56,58,59$ and 68 & $362(78.3)$ & \\
\hline
\end{tabular}

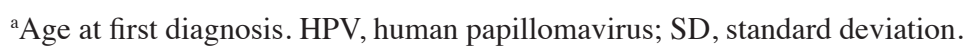

\section{Patients and methods}

Patients and controls. The patients consisted of 462 females with histologically-determined cervical carcinoma, according to the International Federation of Gynecology and Obstetrics. All the females were enrolled between April 2007 and January 2014 at the Department of Radiotherapy, Greater Poland Cancer Center (Poznań, Poland; Table I). The controls included 497 unrelated healthy female volunteers, who were matched by age to the patients (Table I). Data regarding pregnancy, oral contraceptive use, tobacco smoking and menopausal status were obtained during clinical interviews. All individuals were
Caucasian and were enrolled from the Wielkopolska (Greater Poland) area of Poland. The patients and controls provided written informed consent and the study was approved by the Local Ethical Committee of Poznań University of Medical Sciences (Poznań, Poland).

Genotyping. DNA was isolated from peripheral blood leucocytes using a salting-out procedure, in which $10 \mathrm{ml}$ peripheral blood were obtained using BD Vacutainer ${ }^{\circledR}$ (Becton Dickinson, Franklin Lakes, NJ USA). The presence of the SDF1-3' G801A (rs 1801157) transition was determined by polymerase chain reaction (PCR) using Dream Taq DNA Polymerase (Thermo Scientific, 
Table II. Association between the stromal cell-derived factor-1-3' 'G801A (rs 1801157) polymorphism and cervical cancer.

\begin{tabular}{|c|c|c|c|c|c|c|c|}
\hline Genotype & $\begin{array}{c}\text { Patient } \\
\text { (frequency) }\end{array}$ & $\begin{array}{c}\text { Control } \\
\text { (frequency) }\end{array}$ & $\begin{array}{l}\text { Odds ratio } \\
(95 \% \mathrm{CI})\end{array}$ & P-value ${ }^{a}$ & $\begin{array}{l}\text { Adjusted odds ratio } \\
\qquad(95 \% \mathrm{CI})^{\mathrm{b}}\end{array}$ & P-value ${ }^{a}$ & $\mathrm{P}_{\text {trend }}$ \\
\hline $\mathrm{G} / \mathrm{G}$ & $289(0.63)$ & $337(0.68)$ & Referent & - & Referent & & \\
\hline $\mathrm{A} / \mathrm{G}$ & $149(0.32)$ & $144(0.29)$ & $1.207(0.914-1.593)$ & 0.1849 & $1.203(0.909-1.591)$ & 0.196 & 0.0484 \\
\hline $\mathrm{A} / \mathrm{A}$ & $24(0.05)$ & $16(0.03)$ & $1.749(0.911-3.57)$ & 0.0892 & $1.296(0.930-1.807)$ & 0.125 & \\
\hline $\mathrm{A} / \mathrm{G}+\mathrm{A} / \mathrm{A}$ & $173(0.37)$ & $160(0.32)$ & $1.261(0.966-1.646)$ & 0.0878 & $1.262(0.964-1.653)$ & 0.090 & \\
\hline $\begin{array}{l}\text { Minor allele } \\
\text { frequency }\end{array}$ & 0.21 & 0.18 & & & & & \\
\hline
\end{tabular}

${ }^{\mathrm{a}} \chi^{2}$ analysis. ${ }^{\mathrm{b}}$ Odds ratios were adjusted by age, pregnancy, oral contraceptive use, tobacco smoking and menopausal status. Significant results are highlighted in bold font. CI, confidence interval.

Vilnius, Lithuania) and a PTC-200 DNA Engine Thermocycler (MJ Research Inc, St. Bruno, QC, Canada). The primer sequence was as follows, 5'-TTATTGTACTTGCCTTATTAGAG-3' and 5'-GTAGTTCACCCCAAAGGACC-3'. The PCR was followed by digestion with $M s p$ I (C/CGG; Thermo Scientific) according to manufacturer's instructions. The $S D F 1-3^{\prime} A$ allele remained uncut at $732 \mathrm{bp}$, whereas the $S D F 1-3^{\prime} G$ allele was cleaved into $456 \mathrm{bp}$ and $276 \mathrm{bp}$ fragments. The DNA fragments were separated by electrophoresis on a $3 \%$ agarose gel and visualized with ethidium bromide staining (Sigma-Aldrich, Poznań, Poland). The presence of the SDF1-3' G801A transition was also confirmed by Sanger sequencing of $15 \%$ of the samples, which were randomly selected.

Statistical analysis. The distinction in genotypic and allelic prevalence between patients and controls, and their genotypic deviation from the Hardy-Weinberg (HW) equilibrium was evaluated using a $\chi^{2}$ test. The polymorphism was assessed for association with cervical cancer incidence using a $\chi^{2}$ test for trend $\left(\mathrm{p}_{\text {trend }}\right)$, odds ratio $(\mathrm{OR})$ and $95 \%$ confidence intervals $(\mathrm{CI})$. Unconditional logistic regression analysis was used to adjust for the effect of confounders, including age, pregnancy, oral contraceptive use, tobacco smoking and menopausal status. $\mathrm{P}<0.05$ was considered to indicate a statistically significant difference.

\section{Results}

Distribution of the SDF1-3' G801A polymorphism in females with cervical cancer. The prevalence of the SDF1-3' G801A genotypes did not exhibit a significant divergence from the $\mathrm{HW}$ equilibrium between the cases and controls. The distribution and adjusted analysis of the SDF1-3' G801A genotypes in females with cervical cancer are presented in Table II.

The frequency of the SDF1-3' A/A genotype was $\sim 1.7$-fold higher in patients compared with controls. The SDF1-3' A/G heterozygous genotype frequency was higher in patients with cervical cancer compared with controls, at 0.32 and 0.29 , respectively. The SDF1-3' minor allele frequency was also higher in patients compared with controls, and was 0.21 and 0.18 , respectively. The P-value of the $\chi^{2}$ test of the trend observed for the SDF 1-3' G801A polymorphism was at the borderline of being statistically significant $\left(\mathrm{p}_{\text {trend }}=0.0484\right)$. Logistic regression analysis did not demonstrate that the SDF1-3' G801A polymorphism was a risk factor for cervical cancer. The adjusted OR for patients with the $\mathrm{A} / \mathrm{G}$, vs. $\mathrm{G} / \mathrm{G}$ genotype was 1.203 (95\% CI=0.909-1.591; $\mathrm{P}=0.196)$, the adjusted $\mathrm{OR}$ for $\mathrm{A} / \mathrm{A}$, vs. $\mathrm{G} / \mathrm{G}$ was 1.296 $(95 \% \mathrm{CI}=0.930-1.807 ; \mathrm{P}=0.125)$ and for $\mathrm{A} / \mathrm{A}$ or $\mathrm{A} / \mathrm{G}, \mathrm{vs} . \mathrm{G} / \mathrm{G}$ was $1.262(95 \% \mathrm{CI}=0.964-1.653 ; \mathrm{P}=0.090)$.

Stratified analysis between the SDF1-3' G801A genotypes and cervical cancer risks. The age adjusted analysis of the SDF1-3' G801A genotypes and cervical cancer risk, stratified by pregnancy, oral contraceptive use, tobacco smoking, and menopausal status is presented in Table III. An increase in cervical cancer risk was observed only among patients with a positive history of tobacco smoking for the adjusted OR with the A/A, vs. G/G genotype at 1.778 (95\% CI=1.078-2.934; $\mathrm{P}=0.0 .0235)$. However, no significant association was observed between SDF1-3' G801A and smoking for the $\mathrm{A} / \mathrm{G}$, vs. GG (1.180; 95\% $\mathrm{CI}=0.731-1.905 ; \mathrm{P}=0.4975)$ or $\mathrm{A} / \mathrm{A}$ or $\mathrm{A} / \mathrm{G}$, vs. A/A genotype $(1.352 ; 95 \% \mathrm{CI}=0.862-2.122$; $\mathrm{P}=0.1877]$. Furthermore, no significant association was observed between SDF1-3' G801A and pregnancy, oral contraceptive use or menopausal status (Table III). No association was observed between the SDF1-3' G801A polymorphism and tumor stage, histological grade or type of tumor (data not shown) on stratification of the patients based on clinical characteristics.

\section{Discussion}

The SDF1-3' A gene variant has been suggested as a factor that upregulates SDF1 $\alpha$ levels, and the SDF1/CXCR4/CXCR7 axis is considered to contribute significantly to the biology and metastasis of several types of cancer $(22,25)$. In addition, the SDF1-CXCR4 interaction has been demonstrated to be important in the progression of cervical cancer (26-30). Wei et al (26) suggested that the progression of cervical tumors is accompanied with an increased production of SDF1 $\alpha$. In addition to these findings, Huang et al (27) demonstrated an increase in the co-expression levels of SDF1/CXCR4 in CIN and cervical carcinoma as a durative process in cervical cancerogenesis. The SDF1-CXCR4 axis initiates invasiveness via changes to the adhesion and secretion of matrix metalloproteinase-2. (OMIM *120360) and promotes the metastasis of tumor cells 
Table III. Stratified analyses between the distribution of stromal cell-derived factor-1-3' G801A genotypes and cervical cancer risks: Pregnancy, oral contraceptive use, tobacco smoking and menopausal status.

\begin{tabular}{|c|c|c|c|c|c|c|c|c|}
\hline \multirow[b]{2}{*}{ Risk factor } & \multicolumn{3}{|c|}{ Patient (n) } & \multicolumn{3}{|c|}{ Control (n) } & \multirow{2}{*}{$\begin{array}{l}\text { Adjusted odds ratio } \\
\qquad(95 \% \mathrm{CI})^{\mathrm{b}}\end{array}$} & \multirow[b]{2}{*}{ P-value ${ }^{d}$} \\
\hline & $\mathrm{G} / \mathrm{G}$ & $\mathrm{G} / \mathrm{A}$ & $\mathrm{A} / \mathrm{A}$ & $\mathrm{G} / \mathrm{G}$ & $\mathrm{G} / \mathrm{A}$ & $\mathrm{A} / \mathrm{A}$ & & \\
\hline \multicolumn{9}{|l|}{ Pregnancy } \\
\hline Ever & 255 & 132 & 20 & 297 & 127 & 14 & $\begin{array}{l}1.200(0.892-1.615)^{\mathrm{a}} \\
1.255(0.879-1.790)^{\mathrm{b}} \\
1.245(0.936-1.656)^{\mathrm{c}}\end{array}$ & $\begin{array}{l}0.228 \\
0.210 \\
0.132\end{array}$ \\
\hline Never & 34 & 17 & 4 & 40 & 17 & 2 & $\begin{array}{l}1.635(0.662-4.038)^{\mathrm{a}} \\
1.801(0.694-4.677)^{\mathrm{b}} \\
1.898(0.798-4.510)^{\mathrm{c}}\end{array}$ & $\begin{array}{l}0.281 \\
0.220 \\
0.143\end{array}$ \\
\hline \multicolumn{9}{|c|}{ Oral contraceptive use } \\
\hline Ever & 131 & 69 & 12 & 146 & 63 & 7 & $\begin{array}{l}1.210(0.797-1.839)^{\mathrm{a}} \\
1.492(0.907-2.453)^{\mathrm{b}} \\
1.293(0.865-1.932)^{\mathrm{c}}\end{array}$ & $\begin{array}{l}0.370 \\
0.113 \\
0.208\end{array}$ \\
\hline Never & 158 & 80 & 12 & 191 & 81 & 9 & $\begin{array}{l}1.083(0.737-1.594)^{\mathrm{a}} \\
1.127(0.713-1.783)^{\mathrm{b}} \\
1.117(0.771-1.621)^{\mathrm{c}}\end{array}$ & $\begin{array}{l}0.682 \\
0.608 \\
0.557\end{array}$ \\
\hline \multicolumn{9}{|l|}{ Smoking } \\
\hline Ever & 99 & 51 & 14 & 113 & 49 & 7 & $\begin{array}{l}1.180(0.731-1.905)^{\mathrm{a}} \\
1.778(1.078-2.934)^{\mathrm{b}} \\
1.352(0.862-2.122)^{\mathrm{c}}\end{array}$ & $\begin{array}{l}0.498 \\
\mathbf{0 . 0 2 5} \\
0.189\end{array}$ \\
\hline Never & 190 & 98 & 10 & 224 & 95 & 9 & $\begin{array}{l}1.165(0.822-1.653)^{\mathrm{a}} \\
1.139(0.715-1.814)^{\mathrm{b}} \\
1.195(0.853-1.674)^{\mathrm{c}}\end{array}$ & $\begin{array}{l}0.390 \\
0.582 \\
0.300\end{array}$ \\
\hline \multicolumn{9}{|l|}{ Menopausal status } \\
\hline Premenopausal & 105 & 55 & 5 & 132 & 56 & 7 & $\begin{array}{l}1.331(0.839-2.111)^{\mathrm{a}} \\
1.003(0.475-2.119)^{\mathrm{b}} \\
1.322(0.844-2.070)^{\mathrm{c}}\end{array}$ & $\begin{array}{l}0.223 \\
0.994 \\
0.221\end{array}$ \\
\hline Postmenopausal & 184 & 94 & 19 & 205 & 88 & 9 & $\begin{array}{l}1.159(0.812-1.653)^{\mathrm{a}} \\
1.490(0.986-2.252)^{\mathrm{b}} \\
1.261(0.898-1.770)^{\mathrm{c}}\end{array}$ & $\begin{array}{l}0.415 \\
0.058 \\
0.181\end{array}$ \\
\hline
\end{tabular}

${ }^{\mathrm{a}}\left(\mathrm{G} / \mathrm{A}\right.$ vs. G/G); ${ }^{\mathrm{b}}\left(\mathrm{A} / \mathrm{A}\right.$ vs. G/G); ${ }^{\mathrm{C}}$ A/A and A/G vs. G/G), ${ }^{\mathrm{d}} \chi^{2}$ analysis. All P-values were adjusted by age. Significant results are highlighted in bold.

toward lymph nodes and the pelvic cavity in patients with cervical cancer $(29,30)$. SDF1 $\alpha$ also provokes significant signal transduction events, including chemotaxis and rescue from apoptosis in cervical cancer cells $(21,30)$. In addition to these findings Majka et al (21) demonstrated that SDF1 $\alpha$ augments cervical cancer cell scattering and supported the nuclear localization of the $\beta$-catenin gene and also increased its target gene expression, cyclin D1. In addition, it was observed that SDF1 $\alpha$ interacts with CXCR4 and leads to the activation of numerous downstream cytoplasmic signaling pathways, which support the invasiveness of cervical cancer (21).

Genetic variants of SDF1 may have an impact on cervical cancer development and its clinicopathological variables. In the present study, the SDF1-3' G801A SNP was not identified as a risk factor for cervical cancer. The present observations are in agreement with those by Maley et al (23) and Tee et al (24), which also observed no association between the SDF1-3' G801A polymorphism and risk of cervical cancer. However, in the present study, the P-value assessment of the trend observed for the SDF1-3' G801A polymorphism was on the borderline of statistical significance. In addition, the present study revealed that the $S D F 1-3^{\prime} \mathrm{A} / \mathrm{A}$ genotype may be a risk for cervical cancer in females with a positive history of tobacco smoking. This is consistent with previous reports suggesting the possible causative role of tobacco consumption in cervical carcinogenesis $(6,31,32)$. However, no other confounding variables, including contraceptive use, menopausal status or parity affected the SDF1-3' G801A polymorphism as a risk factor for cervical cancer.

The SDF1-3' G801A polymorphism has been reported as a risk factor in the development of breast, laryngeal, oral, lung, prostate and hepatocellular carcinoma, as well as lymphoma (33-39). The effect of the SDF1-3' G801A SNP on SDF1 $\alpha$ biosynthesis has been based mainly on the analysis of subjects infected with human immunodeficiency (HIV) (22). The SDF1-3' A variant has been suggested as a genetic variant, 
which increases the production of SDF1 $\alpha$ (22). These findings were consistent with a study by Chang et al (40) who observed that fibroblasts from patients with colon cancer and the SDF1-3' GA or AA genotypes biosynthesized three times more SDF1 $\alpha$ transcript compared with fibroblasts with the GG genotype. In addition, Garcia-Moruja et al (41) demonstrated that the SDF1-3' A transcript variant exhibited a two-fold longer half-life than the SDF1-3' G transcript variant. By contrast, a study by Kimura et al (42), using Epstein-Barr virus-transformed lymphoblastoid cell lines, did not observe any effects of the SDF1-3' G801A SNP on the SDF1 $\alpha$ mRNA levels. In addition to these findings, Watanabe et al (43), using the syncytium model, also observed no correlation between the SDF1-3' G801A SNP gene variant and syncytium-inducing HIV (43).

In conclusion, the present genetic study is the first, to the best of our knowledge, to demonstrate that the SDF1-3' A gene variant may be a risk factor for cervical carcinoma in patients with a positive history of tobacco smoking; therefore this evaluation should be replicated in other independent ethnicities.

\section{Acknowledgements}

The present study was supported by Poznań University of Medical Sciences (grant no. 502-01-01124182-07474). The technical assistance of Ms. Alicja Pinczewska is gratefully acknowledged.

\section{References}

1. Parkin DM, Bray F, Ferlay J and Pisani P: Global cancer statistics 2002. CA Cancer J Clinicians 55: 74-108, 2005.

2. Jemal A, Bray F, Center MM, Ferlay J, Ward E and Forman D: Global cancer statistics. CA. Cancer J Clin 61: 69-90, 2011.

3. Kokawa K, Takekida S, Kamiura S, Kita M, Enomoto T, Kawaguchi R, Saito J, Horie A and Umesaki N: The incidence, treatment and prognosis of cervical carcinoma in young women: a retrospective analysis of 4,975 cases in Japan. Eur J Gynaecol Oncol 31: 37-43, 2010

4. Georgieva S, Iordanov V and Sergieva S: Nature of cervical cancer and other HPV-associated cancers. J BUON 14: 391-398, 2009.

5. Walboomers JM, Jacobs MV, Manos MM, Bosch FX, Kummer JA, Shah KV, Snijders PJ, Peto J, Meijer CJ and Muñoz N: Human papillomavirus is a necessary cause of invasive cervical cancer worldwide. J Pathol 189: 12-19, 1999.

6. Castellsague X and Munoz N: Chapter 3: Cofactors in human papillomavirus carcinogenesis-role of parity, oral contraceptives and tobacco smoking. J Natl Cancer Inst Monogr 20-28, 2003.

7. Bleul CC,Fuhlbrigge RC, Casasnovas JM, Aiuti A and SpringerTA: A highly efficacious lymphocyte chemoattractant, stromal cell-derived factor 1 (SDF-1). J Exp Med 184: 1101-1109, 1996

8. Shirozu M, Nakano T, Inazawa J, Tashiro K, Tada H, Shinohara T and Honjo T: Structure and chromosomal localization of the human stromal cell-derived factor 1 (SDF1) gene. Genomics 28: 495-500, 1995.

9. Broxmeyer HE: Chemokines in hematopoiesis. Curr Opin Hematol 15: 49-58, 2008.

10. Zou YR, Kottmann AH, Kuroda M, Taniuchi I and Littman DR: Function of the chemokine receptor CXCR4 in heamatopoiesis and in cerebellar development. Nature 393: 595-599, 1998.

11. Onai N, Zhang Y, Yoneyama H, Kitamura T, Ishikawa S and Matsushima K: Impairment of lymphopoiesis and myelopoiesis in mice reconstituted with bone marrow-hematopoietic progenitor cells expressing SDF-1-intrakine. Blood 96: 2074-2080, 2008.

12. McGrath KE, Koniski AD, Maltby KM, McGann JK and Palis J: Embryonic expression and function of the chemokine SDF-1 and its receptor, CXCR4. Dev Biol 213: 442-456, 1999.
13. Kim J, Mori T, Chen SL, Amersi FF, Martinez SR, Kuo C, Turner RR, Ye X, Bilchik AJ, Morton DL and Hoon DS: Chemokine receptor CXCR4 expression in patients with melanoma and colorectal cancer liver metastases and the association with disease outcome. Ann Surg 244: 113-120, 2006.

14. Maréchal R, Demetter P, Nagy N, Berton A, Decaestecker C, Polus M, Closset J, Devière J, Salmon I and Van Laethem J-L: High expression of CXCR4 may predict poor survival in resected pancreatic adenocarcinoma. Br J Cancer 100: 1444-1451, 2009.

15. Kajiyama H, Shibata K, Terauchi M, Ino K, Nawa A and Kikkawa F: Involvement of SDF-1alpha/CXCR4 axis in the enhanced peritoneal metastasis of epithelial ovarian carcinoma. Int J Cancer 122: 91-99, 2008.

16. Akashi T, Koizumi K, Tsuneyama K, Saiki I, Takano Y and Fuse H: Chemokine receptor CXCR4 expression and prognosis in patients with metastatic prostate cancer. Cancer Sci 99: 539-542, 2008.

17. Kijima T, Maulik G, Ma PC, Tibaldi EV, Turner RE, Rollins B, Sattler M, Johnson BE and Salgia R: Regulation of cellular proliferation, cytoskeletal function and signal transduction through CXCR4 and c-Kit in small cell lung cancer cells. Cancer Res 62: 6304-6311, 2002.

18. Lee HJ, Kim SW, Kim HY, Li S, Yun HJ, Song KS, Kim S and Jo DY: Chemokine receptor CXCR4 expression, function and clinical implications in gastric cancer. Int J Oncol 34: 473-480, 2009.

19. Oliveira-Neto HH, Silva ET, Leles CR, Mendonça EF, Alencar Rde C, Silva TA and Batista AC: Involvement of CXCL12 and CXCR4 in lymph node metastases and development of oral squamous cell carcinomas. Tumour Biol 29: 262-271, 2008.

20. Yasuoka H, Tsujimoto M, Yoshidome K, Nakahara M, Kodama R, Sanke T and Nakamura Y: Cytoplasmic CXCR4 expression in breast cancer: induction by nitric oxide and correlation with lymph node metastasis and poor prognosis. BMC Cancer 8: 340, 2008.

21. Majka M, Drukala J, Lesko E, Wysoczynski M, Jenson AB and Ratajczak MZ: SDF-1 alone and in co-operation with HGF regulates biology of human cervical carcinoma cells. Folia Histochem Cytobiol 44: 155-164, 2006.

22. Winkler C, Modi W, Smith MW, Nelson GW, Wu X, Carrington M, Dean M, Honjo T, Tashiro K, Yabe D, Buchbinder S, Vittinghoff E, Goedert JJ, O'Brien TR, Jacobson LP, Detels R, Donfield S, Willoughby A, Gomperts E, Vlahov D, Phair J and O'Brien SJ: Genetic restriction of AIDS pathogenesis by an SDF-1 chemokine gene variant. Science 279: 389-393, 1998.

23. Maley SN, Schwartz SM, Johnson LG, Malkki M, Du Q, Daling JR, Li SS,Zhao LP,PetersdorfEW and Madeleine MM: Genetic variation in CXCL12 and risk of cervical carcinoma: a population-based case-control study. Int J Immunogenet 36: 367-375, 2009.

24. Tee YT, Yang SF, Wang PH, Tsai HT, Lin LY, Lee SK, Liao CL, Chang JT and Shih YT: G801A polymorphism of human stromal cell-derived factor 1 gene raises no susceptibility to neoplastic lesions of uterine cervix. Int J Gynecol Cancer 22: 1297-1302, 2012.

25. Sun X, Cheng G, Hao M, Zheng J, Zhou X, Zhang J, Taichman RS, Pienta KJ and Wang J: CXCL12/CXCR4/CXCR7 chemokine axis and cancer progression. Cancer Metastasis Rev 29: 709-722, 2010.

26. Wei M, Liang LZ, Zhang CQ, Xiong Y, Zhang Y, Shen Y and Li JQ: Correlation of CXCR4/CXCL12 overexpression to lymph node metastasis and chronic inflammation in cervical adenocarcinoma. Ai Zheng 26: 298-302, 2007.

27. Huang Y, Zhang J, Cui ZM, Zhao J and Zheng Y: Expression of the CXCL12/CXCR4 and CXCL16/CXCR6 axes in cervical intraepithelial neoplasia and cervical cancer. Chin J Cancer 32: 289-296, 2013.

28. Shen XY, Wang SH, Liang ML, Wang HB, Xiao L and Wang ZH: The role and mechanism of CXCR 4 and its ligand SDF-1 in the development of cervical cancer metastasis. Ai Zheng 27: 1044-1049, 2008.

29. Zhang JP, Lu WG, Ye F, Chen HZ, Zhou CY and Xie X: Study on CXCR4/SDF-1alpha axis in lymph node metastasis of cervical squamous cell carcinoma. Int J Gynecol Cancer 17: 478-483, 2007.

30. Yang YC, Lee ZY, Wu CC, Chen TC, Chang CL and Chen CP: CXCR4 expression is associated with pelvic lymph node metastasis in cervical adenocarcinoma. Int J Gynecol Cancer 17: 676-686, 2007. 
31. Magnusson PK, Lichtenstein P and Gyllensten UB: Heritability of cervical tumours. Int J Cancer 88: 698-701, 2000.

32. Moreno V, Bosch FX, Muñoz N, Meijer CJ, Shah KV, Walboomers JM, Herrero R and Franceschi S: International agency for research on cancer. Multicentric cervical cancer study group: Effect of oral contraceptives on risk of cervical cancer in women with human papillomavirus infection: the IARC multicentric case-control study. Lancet 359: 1085-1092, 2002.

33. de Oliveira KB, Oda JM, Voltarelli JC, Nasser TF, Ono MA, Fujita TC, Matsuo T and Watanabe MA: CXCL12 rs1801157 polymorphism in patients with breast cancer, Hodgkin's lymphoma and non-Hodgkin's lymphoma. J Clin Lab Anal 23: 387-393, 2009.

34. Razmkhah M, Doroudchi M, Ghayumi SM,Erfani N and Ghaderi A: Stromal cell-derived factor-1 (SDF-1) gene and susceptibility of Iranian patients with lung cancer. Lung Cancer 49: 311-315, 2005

35. Chang CC, Chen SC, Hsieh YH, Chen YC, Chen TY, Chu YH, Ma HJ, Chou MC, Tsai HT and Yang SF: Stromal cell-derived factor-1 but not its receptor, CXCR4, gene variants increase susceptibility and pathological development of hepatocellular carcinoma. Clin Chem Lab Med 47: 412-418, 2009.

36. Vairaktaris E, Vylliotis A, Spyridonodou S, Derka S, Vassiliou S, Nkenke E, Yapijakis C, Serefoglou Z, Neukam FW and Patsouris E: A DNA polymorphism of stromal-derived factor-1 is associated with advanced stages of oral cancer. Anticancer Res 28: 271-275, 2008.
37. Hirata H, Hinoda Y, Kikuno N, Kawamoto K, Dahiya AV, Suehiro Y, Tanaka Y and Dahiya R: CXCL12 G801A polymorphism is a risk factor for sporadic prostate cancer susceptibility. Clin Cancer Res 13: 5056-5062, 2007.

38. Zafiropoulos A, Crikas N, Passam AM and Spandidos DA: Significant involvement of CCR2-64I and CXCL12-3a in the development of sporadic breast cancer. J Med Genet 41: e59, 2004.

39. Kruszyna L, Lianeri M, Rydzanicz M, Szyfter K and Jagodziński PP: SDF1-3'A gene polymorphism is associated with laryngeal cancer. Pathol Oncol Res 16: 223-227, 2010.

40. Chang SC, Lin PC, Yang SH, Wang HS, Li AF and Lin JK: SDF-1alpha G801A polymorphism predicts lymph node metastasis in stage T3 colorectal cancer. Ann Surg Oncol 16: 2323-2330, 2009.

41. Garcia-Moruja C, Rueda P, Torres C, Alcamí J, Luque F and Caruz A: Molecular phenotype of CXCL12beta 3'UTR G801A polymorphism (rs1801157) associated to HIV-1 disease progression. Curr HIV Res 7: 384-389, 2009.

42. Kimura R, Nishioka T and Ishida T: The SDF1-G801A polymorphism is not associated with SDF1 gene expression in Epstein-Barr virus-transformed lymphoblastoid cells. Genes Immun 4: 356-361, 2003.

43. Watanabe MA, de Oliveira Cavassin GG, Orellana MD, Milanezi CM, Voltarelli JC, Kashima S and Covas DT: SDF-1 gene polymorphisms and syncytia induction in Brazilian HIV-1 infected individuals. Microb Pathog 35: 31-34, 2003. 